\title{
PENGEMBANGAN UKM TENUN DI KECAMATAN PRINGGASELA SEBAGAI USAHA MENINGKATKAN DAYA SAING PENGUSAHA KECIL DI KABUPATEN LOMBOK TIMUR
}

\author{
Nova Hari Santhi ${ }^{1}$, Saufi Hidayat ${ }^{2}$, Maerisna Saufi ${ }^{3}$ \\ ${ }^{123}$ Program Studi Administrasi Publik STIA Muhammadiyah Selong \\ ${ }^{1}$ novaharisanthi@gmail.com
}

\begin{abstract}
ABSTRAK
Tujuan dari kegiatan ini adalah untuk mendampingi dan pelatihan manajemen dan administrasi usaha, Pengembangan usaha bagi Usaha Mikro, Kecil dan Menengah meliputi: pemasaran produk melalui WEB, retail modern dan manajemen usaha

Mitra dalam pengabdian ini adalah para kelompok Usaha Mikro, kecil dan Menengah UKM Tenun di Kecamatan Pringgasela Lombok Timur.Target yang ingin dicapai dari penelitian ini adalah seluruh stekholder atau para kelompok usaha mampu mengembangkan usaha yang mereka jalankan dengan diberikannya Bimbingan Teknis (Bimtek). Metode yang digunakan untuk memecahkan masalah yang dihadapi oleh mitra adalah dengan cara melakukan pendampingan dan memfasilitasi Pengembangan usaha bisnis, melaui pendampingan seperti desaimg grafis, pemasaran produk melalui WEB, retail modern dan manajemen usaha. Tujuan adalah untuk menjalankan dan mengembangkan usaha mereka, untuk menciptakan ekonomi kreatif pada masyarakat dan dapat memberikan kontribusi untuk perkembangan ekonomi.

Setelah diberikan pelatihan manajemen dan administrasi usaha (pencatatan Laporan Keuangan UKM) kepada UKM Tenun di Pringgasela yang dilakukan pada tanggal 23-25 juli 2018, para UKM mampu membuat catatan-catatan untuk bisa memisahkan antara keuangan pribadi dan keuangan usaha. Pada kegiatan pengelolaan manajemen usaha dan penyusunan administrasi usaha para kelompok UKM diberikan pelatihan pencatatan keuangan secara sederhana dan menyusun bukti-bukti transaksi penjualan dan pembelian dengan adanya pelatihan ini memberikan kemudahan dan pemahaman terhadap pentingnya manajemen usaha yang baik untuk keberlangsungan usaha mereka.
\end{abstract}

\section{Kata Kunci: Pelatihan, Pendampingan dan Pemberdayaan UKM}

\section{ABSTRACK}

The purpose of this activity is to assist and train business management and administration. Business development for Micro, Small and Medium Enterprises includes: product marketing through WEB, modern retail and business management.

Partners in this service are the Micro, Small and Medium Enterprises of Weaving SMEs in Pringgasela District, East Lombok. The target to be achieved from this research is that all stakeholders or business groups are able to develop the business they run by providing technical guidance (Bimtek). The method used to solve the problems faced by partners is to provide assistance and facilitate business business development, through assistance such as graphic design, product marketing through the WEB, modern retail and business management. The aim is to run and develop their business, to create a creative economy in society and to be able to contribute to economic development. 
After being given training in business management and administration (recording SME Financial Statements) to Weaving SMEs in Pringgasela which was conducted on 23-25 July 2018, SMEs were able to make notes to be able to separate personal finances and business finances. In business management activities and in the preparation of business administration, SME groups were given training in simple financial recording and compiling proof of sales and purchase transactions. This training provided convenience and understanding of the importance of good business management for the sustainability of their business.

\section{Keywords: Training, Assistance and Empowerment of SMEs}

\section{PENDAHULUAN}

Pengembangan UKM semakin gencar dilakukan pemerintah dan pihak lainnya untuk meningkatkan kinerja sektor ini.Upaya mencapai pengembangan UKM ini salah satunya dilakukan melalui pengembangan UKM yang dalam pelaksanaan mengacu pada ASEAN Policy Blue Printfor SME Development (APBSD) 2004-2014. Dalam APBSD, pengembangan UKM dilaksanakan melalui lima program yaitu program pengembangan kewirausahaan, peningkatan kemampuan pemasaran, akses kepada keuangan, akses kepada teknologi dan kebijakan yang kondusif.

Pengembangan Usaha Mikro Kecil dan Menengah (UKM) dan Koperasi merupakan Program Kementerian Koperasi dan UKMdilaksanakan dibawah koordinasi Dinas Koperasi dan UKM Provinsi Nusa Tenggara Barat, yang bertujuan untuk mengurangi kemiskinan, pengangguran, dan kesenjangan pembangunan antar wilayah dan sector serta menambah kemampuan untuk berinovasi dan meningkatkan skill yang berbasis Tehnologi dan informasi.

Dasar pemikiran pertama kegiatan pendampingan bimtek bagi para pelaku koperasi dan usaha Mikro, Kecil dan Menengah adalah Undang-undang nomor 25 Tahun 1992 tentang Koperasi dan undang-undang Republik Indonesia No 20 Tahun 2008 tentang UKM, dengan prinsip (1) Menumbuhkan kemandirian, kebersamaan, dan kewirausaahn UKM untuk berkarya dengan prakarsa sendiri, (2) Perwujudan kebijakan publik yang transparan akuntabel, dan berkeadilan, (3) pengembangan usaha berbasis potensi daerah dan berorientasi pasar sesuai dengan kompetensi UKM, (4) meningkatkan daya saing UKM dan (5) penyelenggaraan perencanaan, pelaksanaan dan pengendalian secara terpadu.

Adapun dasar pemikiran kedua dari kegiatan pendampingan bimtek ini adalah tujuan dari Undang-Undang Pemberdayaan UKM yaitu: (1) Mewujudkan struktur perekonomian nasional yang seimbang,berkembang,dan berkeadilan (2) Menumbuhkan dan mengembangkan kemampuan UKM menjadi usaha yang tangguh dan mandiri (3) Meningkatkan peran UKM dalam pembangunan daerah,penciptaan lapangan kerja,pemerataan pendapatan,pertumbuhan ekonomi,dan pengentasan kemisikinan

Sebagai program pemberdayaan Koperasi dan UKM diawali dengan proses peningkatan kapasitas sumberdaya manusia sebagai pelaksana kegiatan Koperasi dan UKM diawali di lapangan. Melalui kegiatan pendampingan, diharapkan permasalahan UKM dari aspek permodalan, akses pasar dan teknologi, serta masih lemahnya manajemen usaha dapat ditangani melalui Pendampingan. 
Mitra dalam kegiatan ini adalah Usaha Mikro, Kecil dan Menegah yang berada di Desa Pringgasela Kecamatan Pringgasela. Para Kelompok UMKM ini merupakan wirausahawan baru dan wirausahan lama yang mulai mendirikan usaha sekitar tahun 2005 dan ada juga yng baru sekitar tahun 2014. Tujuan dibentuknya kelompok UMKM ini adalah untuk dapat memberikan nilai jual yang lebih tinggi lagi pada produk yang dihasilkan oleh masyarakat sekitar. Adapun kain tenun dapat diolah menjadi tas, sepatu, cendra mata dll.

Permasalahan yang dihapadioleh Mitra dalam kegiatan ini adalah kurang adanya inovasi terhadap kain tenun yang di produksinya, kain tenun yang di produksi hanya berupa selendang panjang saja sementara kain tenun itu dapat dimodivikasi menjadi berbagai macam cinderamata seperti, pembuatan tas menggunakan kain tenun, sepatu dll. Selain itu juga permasalahan yang dihadapi oleh mitra dalam kegiatan ini adalah belum tertibnya addministrasi dan manajemen usaha yang mereka jalankan dengan baik dan benar, belum mampu membuat laporan keuangan secara sederhana dan belum mampu memisahkan antara keuangan pribadi denagan keuangan usaha.

Oleh karena itu berbekal pengetahuan dan pengalaman di bidang pendampingan UKM ketua dan aggota tim akan membantu mangatasi permasalah yang di hadapi oleh Kelompok UKMK ini dengan cara memberikan pendampingan dan memfasilatsi Pengembangan usaha bisnis agar para kelompok binaan mendapatkan peralatan yang memadai untuk mengembangkan usaha mereka, memfasilitasi pembuatan kelengkapan administrasi usaha para kelompok UKM dan melakukan pendampingan untuk memasarkan dan memanajemen usaha mereka agar mampu bersaing dan mampu membuat inovasi untuk produk mereka.

Diharapkan dengan adanya pendampingan dan fasilitasi melalui Program Bussines Development Service ini para kelompok UKM dapat membuat inovasi terbaru pada produk yang dihasilkan sehingga memiliki nilai jual dan daya saing yang lebih tinggi lagi.Dengan diberikan pendampingan ini para pelaku usaha dapat membuat administrasi dan kelengkapan usahanya dengan baik serta mampu memiliki izin usaha dan legalitas lainnya.Dapat mengembangkan usaha yang mereka jalankan sehingga dapat memberikan kontribusi untuk pertumbuhan perekonomian masyarakat sekitarnya.

\section{METODE}

Pelaksanaan pendampingan dan fasilitasi Pengembangan Program Bussines Development Service ini dimulai dari pendataan para kelompok UKM yang usahanya memiliki potensi yang diharapkan.Sesungguhnya kegiatan ini telah dimulai pada saat penyusunan proposal.Namun pada tahapan ini dilakukan observasi secara lebih teliti dan menyeluruh.Tujuan dari pelaksanaan observasi ini untuk mendapatkan data mengenai kesulitan yang dihadapi mitra terkait dengan tema kegiatan ini.

Dari observasi kemudian didapatkan beberapa temuan,

1. Para kelompok UKMK produk yang dihasilkan belum mampu melakukan inovasi yang dapat menarik pembeli sehingga barang yang dijual tidak memiliki harga jual yang tinggi.

2. Para Kelompok UKM belum mempunyai alat produksi yang dapat menunjang untuk melakukan inovasi produk, selain itu juga lembaga mitra belum memiliki legalitas usaha. 
3. Para Kelompok UKM belum mampu melakukan administrasi dan manajemen usaha serta pengelolaan keuangan dengan baik dan benar, karena kurangnya pengetahuan yang dimiliki.

Hasil observasi menjadi salah satu bahan penting dalam pelaksanaan penelitian ini. Cara yang akan ditempuh untuk menyelesaikan permasalahan yang dihadapi oleh mitra adalah dengan memberikan bimbingan teknis yang akan dilakukan oleh Dinas Koperasi dan UKM Provinsi NTB selain itu juga perlu dilakukan pendampingan dan fasilitasi Pengembangan usaha bisnis melalui pengembangan Program Bussines Development Service. Untuk lebih jelasnya berikut akan diuraikan prosedur kerja pada pendampigan dan fasilatasi Pengembangan usaha bisnis sebagai berikut :

1. Pendataan kelompok UKM oleh Tim dan Anggota.

2. Pelaksanaan pendampingan bagi kelompok UKM meliputi pendampingan pengelolaan manajemen dan penyusunan Administrasi Usaha serta pembukuan keuangan yang baik dan benar. Pada kegiatan ini para pelaku UKM diajarkan pencatatan laporan keuangan secara sederhanadan pencatatan pemisahan antara uang pribadi dengan uang usaha

3. Pelaksanaan pendampingan bagi kelompok UKM meliputi pendampingan dan fasilitator kerja sama pemasaran dengan pihak retail modern dan fasilitasi pelatihan pemasaran berbasis web atau internet. Pada kegiatan ini para pelaku UKM diberikan pemahaman bagaimana cara memasarkan produk mereka melalui media social seperti market place dll.

4. Evaluasi kegiatan yang dilakukan selama pendampingan.

Dalam kegiatan ini diharapkan kelompok UKM dapat menciptakan inovasiinovaasi terbaru untuk produk yang mereka hasilkan, selain itu juga diharapkan para kelompok UKM dapat mengelola manajemen dan administrasi usaha dengan baik dan benar karena hal ini dapat menunjang keberlangsungan dari usaha yang dijalankan, agar usaha tersebut dapat menjadi produk unggulan daerah yang dapat bersaing di kancah MEA.

\section{HASIL DAN PEMBAHASAN}

Setelah pelaksanaan kegiatan pengabdian pada masyarakat pada kelompok UKM Tenun di Pringgasela, para kelompok UKM diberikan pendampingan. Kegiatan pendampingan ini meliputi pengelolaan manajemen usaha dan penyusunan administrasi usaha dengan baik dan benar dan memjadi fasilitator kerja sama dengan pihak retail modern.

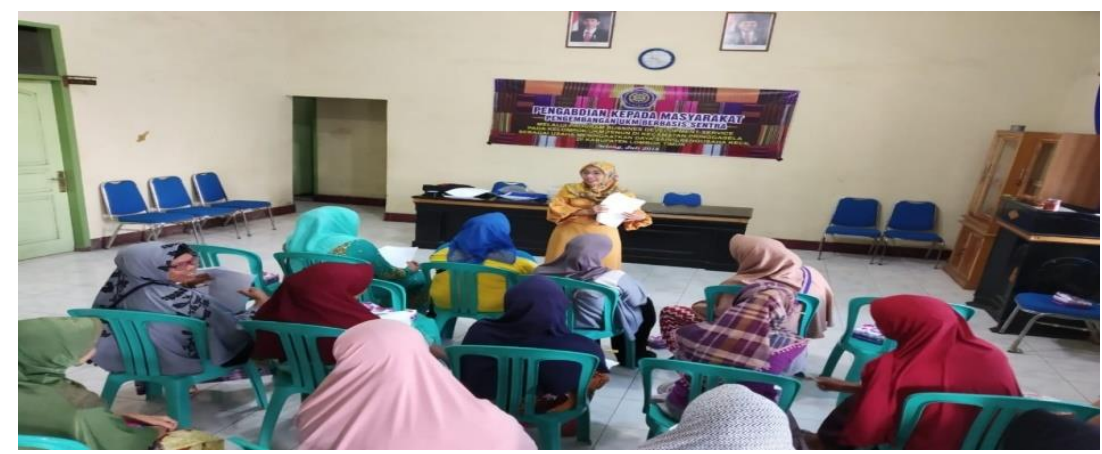

Gambar 1.Pendampingan Manajemen Usaha dan penyusunan laporan keuangan secara sederhana 
Pengelolaan manajemen usaha dan penyusunan administrasi usaha merupakan hal yang sangat penting dalam mengembangkan usaha yang dijalankan.Pada kegiatan pengelolaan manajemen usaha dan penyusunan administrasi usaha para kelompok UKM diberikan pelatihan pencatatan keuangan secara sederhana dan menyusun bukti-bukti transaksi penjualan dan pembelian dengan adanya pelatihan ini memberikan kemudahan dan pemahaman terhadap pentingnya manajemen usaha yang baik untuk keberlangsungan usaha mereka.

Dengan memberikan pelatihan administrasi dan manajemen usaha para UKM telah mampu membuat laporan keuangan secara sederhana dan telah mampu memisahkan antara keuangan pribadi dengan keuangan usaha. Selain itu juga para UKM telah berhasil menata administrasi usaha yang mereka jalankan dengan baik dan benar.

Selain pelatihan administrasi dan manajemen usaha, kami juga memberikan pelatihan pemasaran produk melalui web internet atau media social, dimana kami memberikan pengarahan untuk para UKM cara memasarkan produk agarmudah terjangkau atau mampu diakses oleh pihak luar dengan cara memasarkan produk mereka melalui media social, media social yang kami ajarkan adalah Facebook (FB)memasarkan produk melalui marketplace.

Dengan adanya pemasaran melalui WEB internet melalui media social ini produk-produk UKM dapat dipasarkan hingga keluar Provinsi, hal ini mampu meningkatkan penjualan para UKM dan mampu meningkatkan keuntungan yang di daptkan. Dengan adanya pemasaran melalui media social ini produk-produk UKM sekarang penjualannya tidak hanya pada satu kecamatan saja akan tetapi bias sampai ke beberapa provinsi yang ada di Indonesia.

Dengan adanyan PKM ini dapat membantu kelompok UKM untuk mengembangkan produk yang mereka hasilkan dengan memberikan inovasi-inovasi terbaru, memperluas jaringan pemasaran, mampu mengelola manajemen usaha dengan baik dan dapat meningkatkan kualitas SDM yang dimiliki.Untuk kedepannya para pelaku UKM diharapkan mampu membuat produk yang dapat bersaing secara nasional maupun internasional (Kancah MEA). Para pelaku UKM harus tetap didampingi oleh instansi terkait agar apa yang diinginkan dapat terwujud.

Pelaku Usaha atau UKM tenun yang berada di desa Pringgasela sanagat antusias dengan adanya kegiatan pengabdian ini, pendampingan dan pemberdayaan UKM yang dilakukan ini memberikan dampak yang positif bagi para UKM.Dengan adanya kegiatan ini dapat memberikan pengetahuan bagi UKM tentang mengelola manajemen usaha dengan baik dan mampu membuat laporan keuangan walaupun dengan metode yang sederhana.Selain itu juga dengan adanya kegiatan ini para UKM dapat mengetahui alur pembuatan legalitas usaha seperti mendaptarkan hak cipta, merek dll.

Kegiatan pemberdayaan ini dapat memberikan ide-ide ataupun inovasi yang baru untuk produk yang mereka ciptakan.Sehingga diharapkan dengan adanya kegiatan ini produk UKM dapat bersaing di kancah Nasional mapun Internasional.Selain itu juga kegiatan ini telah mampu mencapai tujuan akhir dari kegiatan ini dantelah mampu memberikan nilai-nilai yang positif bagi para UKM. 
Diagram 1. Gambaran Iptek yang di transfer kepada mitra

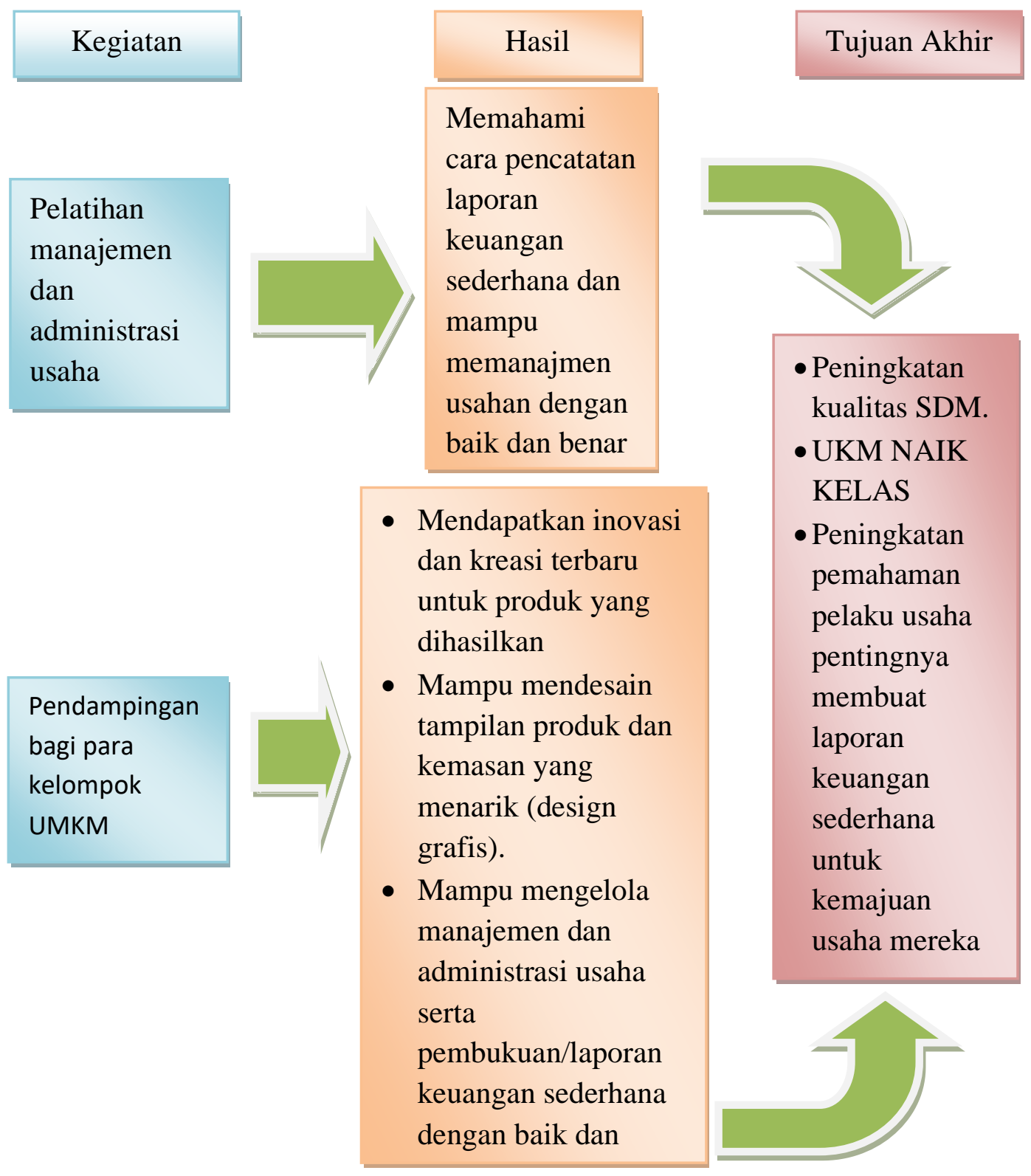

\section{KESIMPULAN}

Kegiatan pendampingan ini sangat penting bagi para pelaku usaha atau UKM.Kegiatan ini dapat memberikan pengetahuan dan keterampilan untuk para UKM dalam membenahi Usaha yang telah dijalankan.Dengan adanya pendamipngan atau pemberdayaan ini para pelaku usaha diharapkan mampu melakukan inovasi terbaru maupun terobosan terhadap produk yang mereka miliki sehingga ke depannya produk yang mereka hasilkan diharpkan mampu bersaing dengan produk yang lainnya dan mampu dipasarkan hingga ke berbagai daerah dan mampu bersaing ke kancang nasional maupun internasional. 


\section{UCAPAN TERIMA KASIH}

Ucapan Terima kasih ditunjukan kepada Kepala Desa Pringgasela yang telah memfasilitasi kegiatan pengabdian ini, selain itu juga disampaikan ucapan terima kasih kepada para UKM Tenun yang telah bersedia meluangkan waktu untuk kelancaran kegiatan ini.Ucapan terima kasih juga diberikan kepada lembaga penelitian dan Pengabdian Masyarakat (LPPM) STIAMuhammadiyah Selong yang telah mensuport kegiatan pengabdian ini.

\section{REFRENSI}

Sugiyono. 2010. Metode penelitian Kuantitatf Kualitatif dan R\&D. Bandung: Alfabeta Undang-Undang Republik Indonesia Nomor 20 Tahun 2008 Tentang Usaha Mikro, Kecil dan Menengah.

Undang-Undang Republik Indonesia Nomor 25 Tahun 1992 Tentang Perkoperasian Indonesia. 